\title{
Erratum: HIV vaccine controversy
}

\section{K S Jayaraman}

Nat. Biotechnol.26, 256 (2008); published online 7 March 2008; corrected after print 11 July 2008

In the version of this article initially published, the author reported that "trial participants now test seropositive for HIV and are 'unable to convince their employers that their HIV status was vaccine induced'” In fact, none of the trial participants tested positive for HIV. The error has been corrected in the HTML and PDF versions of the article.

\section{Erratum: Response to HIV vaccine trials in India}

\section{K S Jayaraman}

Nat. Biotechnol. 26, 496 (2008); published online 8 May 2008; corrected after print 11 July 2008

In the version of this article initially published, the author stated in his response to a letter from Seth Berkley that the results of IAVI's AIDS vaccine trials in Belgium and Germany were "not given to trial subjects and fresh consent obtained." This is incorrect. The European data were shared with trial subjects in India and they were reminded of their option to withdraw from the trial at any time. The error has been corrected in the HTML and PDF versions of the article.

\section{Erratum: Can ‘double blockbuster' strengthen Amgen's backbone?}

\section{Cormac Sheridan}

Nat. Biotechnol. 26, 361-363 (2008); published online 7 April 2008; corrected after print 7 August 2008

In the version of this article initially published, in Table 1, page 362, Protelos was wrongly cited as strontium malonate; in fact, Protelos is the current brand name of strontium ranelate. Unlike strontium malonate, strontium ranelate is approved by the European Medicines Evaluation Agency (EMEA) for the treatment of post-menopausal osteoporosis and has been shown in published clinical trials to decrease the risk of vertebral, nonvertebral and hip fractures in post-menopausal osteoporosis. The error has been corrected in the HTML and PDF versions of the article.

\section{Erratum: Biotech slumps in Q1}

Stacy Lawrence

Nat. Biotechnol. 26, 486 (2008); published online 8 May 2008; corrected after print 7 August 2008

In the version of this article initially published, in the table titled "Notable Q1 biotech deals," under Mergers and acquisitions, Warburg Pincus was incorrectly given as the Target and Lifecore Biomedical as the Acquirer. In fact, Warburg Pincus was the Acquirer and Lifecore Biomedical the Target. The error has been corrected in the HTML and PDF versions of the article. 